\title{
Abietane Acids: Sources, Biological Activities, and Therapeutic Uses
}

\author{
Arturo San Feliciano ${ }^{1,2}{ }^{2}$, Marina Gordaliza ${ }^{1}$, Miguel A. Salinero ${ }^{1}$, and José M. Miguel del Corral ${ }^{1}$ \\ ${ }^{1}$ Laboratorio de Química Farmacéutica, Facultad de Farmacia, Universidad de Salamanca, E-37007 Salamanca, Spain \\ ${ }^{2}$ Address for correspondence
}

Received: February 15, 1993; Revision accepted: April 27, 1993

\begin{abstract}
The biological activities of natural abietane acids and their derivatives have been reviewed from 1967 to 1992. Antimicrobial, antiulcer, and cardiovascular activities are the most representative for this class of diterpenoids, while others like allergenic, antiallergic, filmogenic, surfactant, antifeedant, etc. activities, which determine several uses of abietane acids, have also been reported.
\end{abstract}

\section{Key words}

Abietane acids, antimicrobial, antiulcer, cardiovascular, toxicity.

\section{Introduction}

Abietane acids are a group of phenanthrene diterpenoids which do not seem to have been the object of a recent pharmacological review. Nevertheless, they seem to merit attention, due to their varied biological activities and the folk-medicinal uses of extracts containing them as well as their toxicities and secondary effects.

The main source of abietane acids is colophony, the distillation residue of pine resins. Directly, or after stabilization through partial polymerization or dehydrogenation, this product is mainly used in the paints, varnishes, and coatings industries. The acid part of colophony is composed of abietic acid (15), its equilibrium isomers levopimaric (23), palustric (21), and neoabietic (24) acids, and dehydroabietic acid (27), as well as some other non-abietanic compounds.

Additionally, abietane acids are components of extracts or resins from many other conifers belonging to the families Araucariaceae, Cupressaceae, Pinaceae, and Podocarpaceae, but they also occur in several Angiosperm species and, particularly, in the families Asteraceae, Celastraceae, Hydrocharitaceae, and Lamiaceae.

\section{Structure and Occurrence}

The skeletal structure and numbering of abietane acids are exemplified by that of abietic acid (15). It displays an equatorial carboxylic group (C-18) and two conjugated double bonds at positions 7 and 13 . In other natural congeners the carboxylic group adopts the axial configuration (C-19) or represents C-20 while the number and positions of double bonds varies from one to four and are predominantly located on ring $\mathrm{C}$, giving rise to a particular type of aromatic diterpenoids commonly known as dehydroabietic derivatives. Other functionalities such as hydroxy and carbonyl groups are often present and in some substances an endoperoxide moiety can also be found. Natural abietanic acids reported in the literature (1-65) and covered by Chemical Abstracts (1967 to date) and MEDLINE (1985 to date) are arranged in Tables 1 and 2 according to the number of double bonds and/or the location of the carboxylic group in the skeleton.

\section{Biological Activities and Uses}

The use of pine resin as a whole or its derivatives, essence, and colophony as expectorants, modifiers of bronchial secretions, and antiseptics for the urinary tract, as well as rubefacients and vessicants in poultices and creams in veterinary practice is described in several Pharmacognosy and Medicinal Plant treatises $(66,67)$. In recent years (1967-1992), studies on the biological activities of abietane acids have been performed with pure compounds and activities like antimicrobial, antiulcer, cardiovascular, allergenic, antiallergic, and many uses in cosmetics and dermatologic preparations have been reported for some of them.

\section{Antimicrobial Activity}

The antimicrobial activity of pisiferic acid (48) and its derivatives has been established against Pseudomonas, Proteus, and Klebsiella (68) as have its antibacterial actions against Gram-positive microorganisms, its antifungal activity, and its activity in experimental carcinoma of the uterus (HeLa- $\mathrm{S}_{3}$ cells) $(55,58)$. In the systems assayed, pisiferic acid (48) was active against Proteus vulgaris, Staphylococcus aureus, Bacillus subtilis, Pyricularia oryzae, and HeLa-S $\mathrm{S}_{3}$ cells, while methylation of the 


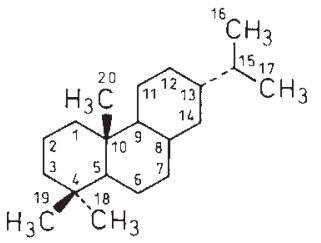

\begin{tabular}{|c|c|c|c|}
\hline Acid & Structure & Plant (Family) ${ }^{*}$ & Ref. \\
\hline 13-epi-8-abieten-18-oic & 1 & Cistus ladaniferus (Ci) & 1 \\
\hline $14 \alpha$-hydroxy-13-epi-8-abieten-18-oic. (suaveolic acid) & 2 & Hyptis suaveolens $\{$ La) & 2 \\
\hline 13-hydroxy-7-oxo-8(14)-abieten-18-oic & 3 & Larix kaempferi(Pi) & 3 \\
\hline $9 \beta, 13 \beta$-epidioxy-8(14)-abieten-18-oic & & & \\
\hline (palustric acid $\beta$-endoperoxide) & 4 & Elodea canadensis (Hy) & 4 \\
\hline $9 \alpha, 13 \alpha$-epidioxy-8(14)-abieten-18-oic & & & \\
\hline (palustric acid $\alpha$-endoperoxide) & 5 & Elodea canadiensis (Hy) & 4 \\
\hline $3 \beta$-hydroxy-9 $\alpha, 13 \alpha$-epidioxy-8(14)-abieten-18-oic & 6 & Salvia oxyodon(La) & 5 \\
\hline $3 \beta$-acetoxy-9 $\alpha, 13 \alpha$-epidioxy-8(14)-abieten-18-oic & 7 & Salvia oxyodon (La) & 5 \\
\hline $7 \beta$-hydroxy-9 $\alpha, 13 \alpha$-epidioxy-8(14)-abieten-18-oic & 8 & Lepichinia caulescens (La) & 6 \\
\hline 8,15-dihydroxy-13-abieten-18-oic & 9 & Larix sibirica $(\mathrm{Pi})$ & 3 \\
\hline 8-hydroxy-12-oxo-13-abieten-18-oic & 10 & Pinus sylvestris (Pi) & 7 \\
\hline $8 \alpha, 12 \alpha$-epidioxi-13-abieten-18-oic & 11 & Abies marocana $(\mathrm{Pi})$ & 8 \\
\hline 9-hydroxy-7-oxo-15-abieten-18-oic (wiedemanic acid) & 12 & Salvia wiedemannii (La) & 9 \\
\hline $13 \alpha$-methoxy-8(14)-abieten-19-oic & 13 & Juniperus phoenicea (Cu) & 10 \\
\hline $9 \alpha, 13 \alpha$-epidioxi-8(14)-abieten-19-oic & 14 & Juniperus sabina (Cu) & 11,12 \\
\hline 7,13-abietadien-18-oic (abietic acid) & 15 & Pinus sp. $(\mathrm{Pi})$ & $13-18$ \\
\hline $12 \alpha$-hydroxyabietic & 16 & Pinus sylvestris (Pi) & $8,19,20$ \\
\hline 12-oxoabietic & 17 & Pinus sylvestris (Pi) & 19 \\
\hline 15-hydroxyabietic & 18 & Agathis robusta (Ar) & $20-22$ \\
\hline 15-methoxyabietic & 19 & Cedrus deodara $(\mathrm{Pi})$ & 22 \\
\hline 7,13-abietadien-19-oic (4-epi-abietic acid) & 20 & Juniperus phoenicea (Cu) & $12,13,23$ \\
\hline 8,13-abietadien-18-oic (palustric acid) & 21 & Pinus palustris ( $\mathrm{Pi})$ & $24-27$ \\
\hline 8,13-abietadien-19-oic (4-epi-palustric acid) & 22 & Juniperus phoenicea (Cu) & 23 \\
\hline 8(14),12-abietadien-18-oic (levopimaric or sapietic acid & id) 23 & Pinus sylvestris (Pi) & $28-31$ \\
\hline $8(14), 13(15)$-abietadien-18-oic (neoabietic acid) & 24 & Pinus palustris (Pi) & $25,27,32-34$ \\
\hline 8(14),13(15)-abietadien-19-oic (4-epi-neoabietic acid) & 25 & Juniperus sabina (Cu) & 18 \\
\hline 11,14-dioxo-8,12-abietadien-19-oic (gymindione) & 26 & Gyminda costarricensis (Ce) & 35 \\
\hline
\end{tabular}

Table 1 Structures and sources of abietene and abietadiene acids.

${ }^{*}$ Abbreviations: $\mathrm{Ar}=$ Araucariaceae, $\mathrm{As}=$ Asteraceae, $\mathrm{Ce}=$ Celastraceae, $\mathrm{Ci}=$ Cistaceae, $\mathrm{Cu}=$ Cupressaceae,

$\mathrm{Hy}=$ Hydrocharitaceae, $\mathrm{La}=$ Lamiaceae, $\mathrm{Pi}=$ Pinaceae, $\mathrm{Po}=$ Podocarpaceae

acid or phenol group abolished its activity against Proteus and Pyricularia, respectively. Methylation of both groups simultaneously abolishes almost all antimicrobial activity, although its effect on HeLa-S 3 cells persists (57).

Structure-activity relationship studies have been performed in the light of these findings. In the case of the activity against Gram-negative bacteria, a carboxy group at $\mathrm{C}-10$ is clearly necessary. The hydroxy group at position 12 seems to be a requirement for antibacterial activity against Gram-positive organisms, and is an indispensable structural requirement for antifungal activity since the $O$-methyl derivatives are inactive. However, the cytotoxicity does not seem to be determined by any specific structural factor.

Comparative studies have also been conducted on the antimicrobial actions of pisiferic (48), dehydroabietic (27), and podocarpic acids and ferruginol; the results have shown that the aromatic ring $\mathrm{C}$ and the isopropyl group are necessary for the Gram-positive antibacterial action. The authors also concluded that the hydroxy group ortho to the isopropyl group increases antimicrobial activity whereas a change of the carboxy group to position 4 decreases it (56). Abietic (15), dehydroabietic (27), and neoabietic (24) acids are the main compounds re- sponsible for the antibacterial activity of the mixture of resin acids $(69-71)$.

The lipid nature of the derivatives of pisiferic acid (48) has been correlated with their antimicrobial potencies, it being concluded that the greater lipophilicity leads to higher activity against Gram-positive bacteria (Bacillus subtilis and Staphylococcus aureus) while a lower degree of lipophilicity elicits an increase in activity against Proteus vulgaris (68).

Pisiferic acid (48), $\Delta^{8}$-dihydroabietic (1), and dehydroabietic (27) acids show antifungal properties when formulated in a fungicidal powder for use against the disease in rice caused by Pyricularia oryzae (72). The tuberculostatic activity of dehydroabietylguanidine, active against Mycobacterium tuberculosis and some bacteria, is also interesting due to its low toxicity (73).

\section{Antiulcer Activity}

Another of the properties studied in the abietic acids is their capacity to inhibit gastric secretions, suggesting their possible use as antiulcer compounds. In a program aimed at searching for new antiulcer agents with a broad cytoprotective effect, Wada et al. (74) prepared 


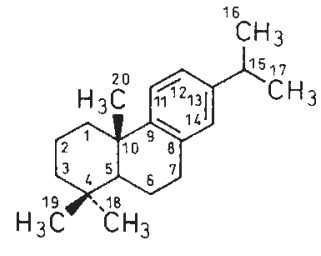

Acid

\begin{tabular}{|c|c|c|}
\hline ucture & Plant (Family) ${ }^{*}$ & Ref. \\
\hline 27 & Pinus sp., Cedrus sp. $(\mathrm{Pi}) 1$ & $13,25,26,36-39$ \\
\hline 28 & Salvia oxyodon (La) & 5 \\
\hline 29 & Cedrus deodara (Pi) & 22 \\
\hline 30 & Pinus sp. (Pi) & 38,40 \\
\hline 31 & Pinus sylvestris ( $\mathrm{Pi}$ ) & 19 \\
\hline 32 & Agathis robusta (Ar) & $27,38,39$ \\
\hline 33 & Cedrus deodara $(\mathrm{Pi})$ & 39 \\
\hline 34 & Pinus silvestris ( $\mathrm{Pi})$ & $19,38,39,41$ \\
\hline 35 & Larix kaempferi (Pi) & 3 \\
\hline 36 & Pinus nigra $(\mathrm{Pi})$ & $41-43$ \\
\hline 37 & Pinus abies (Pi) & 41,44 \\
\hline 38 & Salvia tomentosa (La) & 37 \\
\hline 39 & $\begin{array}{l}\text { Callitris } \\
\text { collumellaris }(\mathrm{Cu})\end{array}$ & $12,13,18,45-49$ \\
\hline 40 & Juniperus phoenicea (Cu) & 13,18 \\
\hline 41 & Podocarpus lambertius ( $\mathrm{P}$ & 50 \\
\hline 42 & Juniperus phoenicea (Cu) & 13,18 \\
\hline 43 & Gyminda costarricensis (C) & 51 \\
\hline 44 & $\begin{array}{l}\text { Podocarpus } \\
\text { dacrydioides (Po) }\end{array}$ & $50,52-54$ \\
\hline 45 & Podocarpus comosum $(\mathrm{Po}$ & 50 \\
\hline 46 & Gyminda costarricensis IC & (Ce) \\
\hline 47 & Gyminda costarricensis (C) & (Ce) \\
\hline 48 & Chamaecyparis pisifera ( $\mathrm{C}$ & (Cu) $55-57$ \\
\hline 49 & Chamaecyparis pisifera (C & (Cu) $56-59$ \\
\hline 50 & Salvia officinalis (La) & 60,61 \\
\hline 51 & Salvia lanigera (La) & 62 \\
\hline 52 & Salvia canariensis (La) & 63 \\
\hline 53 & Salvia canariensis (La) & 63 \\
\hline 54 & Salvia canariensis (La) & 63 \\
\hline 55 & Salvia apiana (La) & 64 \\
\hline 56 & Lepechinia meyeni(La) & 65 \\
\hline
\end{tabular}

8,11,13-abietatrien-18-oic-(dehydroabietic acid) $3 \beta$-hydroxydehydroabietic

$7 \beta$-hydroxydehydroabietic

$7 \alpha$-hydroxydehydroabietic

12-hydroxydehydroabietic

15-hydroxydehydroabietic

$7 \beta, 15$-dihydroxydehydroabietic

7-oxodehydroabietic

15-hydroxy-7-oxodehydroabietic

6,8,11,13-abietatetraen-18-oic

8,11,13,15-abietatetraen-18-oic

$3 \beta$-hydroxy-8,11,13,15-abietatetraen-18-oic

8,11,13-abietatrien-19-oic (callitrisic acid)

$7 \alpha$-hydroxycallitrisic

12-hydroxycallitrisic (lambertianic acid)

7-oxocallitrisic

14-hydroxycallitrisic

12,16,17-trihydroxycallitrisic (pododacric acid)

12-0-acetylpododacric

11,14-dihydroxycallitrisic

11,14-dimethoxycallitrisic

12-hydroxy-8,11,13-abietatrien-20-oic (pisiferic acid)

0 -methylpisiferic

11,12-dihydroxy-8,11,13-abietatrien-20-oic (carnosic acid)

12-0-methylcarnosic

7-oxocarnosic

6-oxo-7 $\beta$-hydroxycarnosic

6-oxo-7 $\alpha$-hydroxycarnosic

16-hydroxycarnosic

12-formyl-11-hydroxy-8,11,13-abietatrien-20-oic
Table 2 Abieta-8,11,13-triene (dehydroabietic) acids and their occurrences.

-Abbreviations: $\mathrm{Ar}=$ Araucariaceae, $\mathrm{Ce}=$ Celastraceae, $\mathrm{Cu}=$ Cupressaceae, $\mathrm{La}=$ Lamiaceae $, \mathrm{Pi}=\mathrm{Pinaceae}, \mathrm{Po}=$ Podocarpaceae.

more than sixty derivatives of dehydroabietic acid (27), introducing a hydrophilic residue (amino, carbamoyl, carbamate, ureide, sulfonyl, or sulfamoyl) on the lipophilic residue of the dehydroabietane moiety and evaluated the antisecretory and antipeptic activity. The results obtained showed that dehydroabietic acid (27) has a moderate antisecretory action ( $22 \%$ inhibition of secretion at an oral dose of $30 \mathrm{mg} / 100 \mathrm{~g}$ in the rat) although it lacks antipeptic activity. These activities were overcome by amides and other nitrogen derivatives at position 18.

Additionally, the antipeptic activity was very high in the salts of 12-sulfodehydroabietic acid (75), suggesting that the presence of two acid functions in the molecule is a requirement for antipeptic activity to appear. These derivatives have cytoprotective properties and lack the collateral mineralocorticoid effects shown by other antiulcer agents. For this reason, several of the derivatives of 12 -sulfodehydroabietic acid have been reported as being useful therapeutical and prophylactic agents in gastrointestinal disease (ulcers, gastritis) free of collateral effects and with a low degree of toxicity $(76-82)$. Recently, the ability of abietic acid (15) to inhibit the secretion of gastric acid caused by $\left(\mathrm{H}^{+}, \mathrm{K}^{+}\right)$-ATPase has been described (83).

\section{Cardiovascular Activities}

Reports have appeared on effects of abietic (15) and dehydroabietic (27) acids on serum cholesterol levels (84) that have induced the search for hypocholesterolemic derivatives more potent than natural ones (85). Thus, the primary amides of tetrahydroabietic and $\Delta^{8}$-dihydroabietic (1) acids do not display hypocholesterolemic activity and the $\mathrm{N}$-alkyl secondaries lead to increases in serum cholesterol levels, whereas the presence of benzene rings in the substituent increases the hypocholesterolemic activity to a considerable extent (86). Additionally, the antiarrhythmic effect of $\mathrm{N}$-[2-(diethylamino)ethyl]dehydroabietamide is higher than that of procainamide, although it is less effective than guanidine. The antithrombotic action of abietic acid (15) has also been described (87). 
Dehydroabietic acid (27), together with $p$ coumaric acid, have been considered the main antinicotinic substances of the oleoresin from Pinus densiflora both in vitro and in vivo (88); at a dose of $10 \mu \mathrm{g} /$ cigarette it is able to reduce the hypertensive and tachycardic effects of tobacco and administered intravenously it produces vasodilation, blocking the arterial constriction caused by nicotine (89). Abietic acid (15) inhibits $\left(\mathrm{Na}^{+}, \mathrm{Ka}^{+}\right)$-ATPase at concentrations of $25 \mathrm{mg} / \mathrm{ml}$ in a non-specific way (83), suggesting that this acid, like other biologically active diterpenoids, could essentially elicit disorganization of the cell membrane.

\section{Other Activities and Uses}

The allergenic and antiallergic power of the acid components of resins has been debated in depth and is controversal. Abietic acid (15), considered as the classic allergen involved in contact with colophony, has been proven to be non-allergenic $(90-92)$ and is indeed used in antiallergic formulations (93). By contrast, one product of its autooxidation, 15-hydroperoxyabietic acid and other abietanic hydroxyacids have been identified as being responsible for the allergic reactions produced by colophony (94-97). In a test on passive anaphylaxis of the skin, it has also been demonstrated that dehydroabietic (27) and $\Delta^{8}$ dihydroabietic (1) acids, their salts and their esters are inhibitors of skin allergies induced by $\operatorname{lgE}(98)$.

The surfactant properties of abietic (15) and dehydroabietic (27) acids, their salts, and their amides with glycine and other amino acids make them useful in the softening of water (99) and they are therefore included in preparations for skin and hair treatments $(100,101)$. Abietic acid (15) has also been described as the active ingredient of certain anti-dandruff shampoos (102) and it is used in the manufacture of nail varnishes and hair glossers (103). The esters of tetrahydroabietic acid are found as components of lipstick, massage creams, and other cosmetic products (104-107).

Other properties that potentiate abietic acids as therapeutic acids are filmogenic. Abietic (15) and neoabietic (24) acids in solution, aerosol, or other pharmaceutical forms are used in cases of severe burns and wounds to protect the skin against infections and parasites (108-109).

A mixture of resinic acids [levopimaric (23), neoabietic (24), palustric (21), abietic (15), and isopimaric acids] and triglycerides has also been indicated in the treatment of chronic diseases such as rheumatism and gout (100). The monoethylamide and diethanolamide of abietic acid are indicated as aromatizing agents (110) in chewing gum and, at high concentrations, palustric acid (21) acts as an antifeedant (98).

\section{Toxic Effects}

Abietic acid (15) is toxic for the pulmonary epithelium; it is a dose- and time-dependent toxic agent and causes the cells of the alveolar epithelium to lyze, possibly causing asthma and chronic pulmonary diseases (111).
However, the best studied toxic effects are those derived from their contamination as micropollutants of water in the paper industry. Its toxicity to Salmo gairdneri (the rainbow trout) (112) has received particular attention, and it has been observed that at concentrations above $15 \mathrm{mg} / \mathrm{l}$ dehydroabietic acid (27) causes a decrease in cellular ATP levels and in the consumption of oxygen and hence an increase in the hemolysis of erythrocytes and the development of jaundice (113). Studies conducted with resinic acids (114) have shown that liver RNA and protein concentrations are altered; all this involves, above certain limits, a subacute toxicity in fish exposed to the effluent of resinic acids from the paper industry. Dehydroabietic acid (27) inhibits the production of methane by Methanosaeta sp. and is the most toxic of all the benzene derivatives assayed (115-116).

\section{Acknowledgements}

Financial support during this work came from DGICYT (Spain) grant PB89/394 is gratefully acknowledged.

\section{References}

1 Tabacik-Woltzka, C., Mousseron, M., Chafai, M. A. (1963) Bull. Soc. Chim. Fr. 2299-2306.

2 Manchand, P. S., White, J. D., Fayos, J., Clardy, J. (1974) J. Org. Chem. 39, 2306-2308

3 Bol'shakova, V. I., Schmidt, E. N., Pentegova, V. A., Mamatyuk, V. I. (1986) Khim. Prir. Soedin 5, 571-576 [Eng. Transl. (1987) Chem. Nat. Comp. 22, 536-541].

4 Monaco, P., Parrilli, M., Previtera, L. (1987) Tetrahedron Lett. 28, $4609-4610$

5 Escudero, J., Perez, L., Rabanal, R. M., Valverde, S. (1983) Phytochemistry 22,585-587.

6 Delgado, G., Sanchez, E., Hernandez, J., Chavez, M. I., Alvarez, L., Martinez, E. (1992) Phytochemistry 31, 3159-3161.

7 Buratti, L., Allais, J. P., Barbier, M. (1990) Phytochemistry 29, 2708-2709.

8 Barrero, A. F., Sánchez, J. F., Alvarez, E. J., Muñoz, M., Haidour, A. (1991) Phytochemistry 30,593-597.

9 Topcu, G., Ulubelen, A. (1990) Phytochemistry 29, 2346-2348.

10 San Feliciano, A., Miguel del Corral, J. M., Gordaliza, M., Moreno de Vega, C., unpublished data.

11 San Feliciano, A., Miguel del Corral, J. M., Gordaliza, M., Castro, M. A. (1991) Phytochemistry 30,695-697.

12 San Feliciano, A., Miguel del Corral, J. M., Gordaliza, M., Salinero, M. A., del Rey, B. (1993) Fitoterapia 64, 185-186.

13 Pascual, J. de, San Feliciano, A, Tabernero, M. L., Miguel del Corral, J. M., Barrero, A. F., Grande, M. (1978) An. Quim. 74, $459-464$.

14 Lavy, S. (1928) Angew. Chem. 41, 233-237.

15 Ruzicka, L., Andersmith, F. (1932) Helv. Chim. Acta 15, 1289-1294.

16 Ruzicka, L., Sternbach, L. (1941) Helv, Chim. Acta 24, 504-515

17 Smith, W. B. (1978) Org. Magn. Reson. 11, 427-428.

18 Pascual, J. de, San Feliciano, A., Miguel, del Corral, J. M., Barrero, A. F. (1983) Phytochemistry 22, 300-301.

19 Roshchin, V. I., Kolodynskaya, L. A., Raldugin, V. A., Pentegova, V. A. (1985) Khim. Prir. Soedin. 3, 345-351.

20 Puzanova, V. Y., Schmidt, E. N., Rabdil, B. A., Pentegova, V. A. (1986) Izv. Sib. Otd. Akad. Nauk. SSR. Ser. Khim. Nauk. 5. 129-132; Chem. Abstr. 106, 34964.

21 Carman, R. M., Marty, R. A. (1970) Austral. J. Chem. 23, $1457-1464$

22 Ohmoto, T., Saito, M., Yamaguchi, K. (1987) Chem. Pharm. Bull. $35,2443-2447$.

23 Tabacik, C., Poisson, C. (1969) Bull. Soc. Chim. Fr. 9, 3264-3265.

24 Wenkert, E., Afonso, A., Bredenberg, J. B., Kaneko, C., Tahara, A. (1964) J. Am. Chem. Soc. 86, 2038-2043.

25 Gough, L. J. (1970) Phytochemistry 9, 1093-1096. 
26 Norin, T., Winell, B. (1972) Acta Chem. Scand. 26, 2289- 2296.

27 Zinkel, D. F., Critchfield, W. B. (1974) Phytochemistry 13, $2876-2877$

28 Ruzicka, L., Balas, F., Willim, F. (1924) Helv. Chim. Acta 7, $458-462$.

29 Burgstahler, A. W., Ziffer, H., Weiss, U. (1961) J. Am. Chem. Soc. $83,4660-4661$

${ }^{30}$ Norin, T., Winell, B. (1972) Acta Chem. Scand, 26, 2297- 2304.

31 Konopleva, N. R., Skvortsov, N, P. (1983) Khim. Drev. 4, 18-20; Chem. Abstr. 99, 106968.

32 Harris, G. C., Sanderson, T. F. (1948) J. Am. Chem. Soc. 334-339.

${ }^{33}$ Audier, H. E., Bory, S., Fetizon, M., Anh, N. T. (1966) Bull. Soc. Chim. Fr. 12, 4002-4010.

${ }^{34}$ Bardysher, I. I., Degtyarenko, A. S., Pertsovskii, A. L., Krynk, S. I. (1981) Khim. Drev. 3, 102-104; Chem. Abstr. 95, 44975.

35 Castro, V., Calzada, J. (1984) Rev. Latinoamer. Quim. 15, $135-136$

${ }^{36}$ Harris, G. C. (1948) J. Am. Chem. Soc. 70, 3671- 3674.

37 Ulubelen, A., Miski, M., Marby, T. J. (1981) J. Nat. Prod. 44, $119-124$.

38 Ayer, W. A., Migaj, B. S. (1989) Can. J. Bot. 67, 1426-1428.

${ }^{39}$ Ohmoto, T., Katanaki, K., Yamaguchi, K. (1987) Chem. Pharm. Bull. 35, 229-234.

40 Roshchin, V. I., Kolodynskaya, L. A., Razina, N. Yu., Solov'ev, V. A. (1985) Khim. Drev. 2, 106-107; Chem. Abstr. 103, 3690.

41 Ekman, R. (1979) Acta Acad. Abo. Ser. B. 39, 1-7; Chem. Abstr. 91, 207623.

${ }^{42}$ Dupont, G., Dolou, R., Thibault, C. (1953) Compt. Rend. Acad. Sci. 236,2408

43 Lorbeer, E., Kratzl, K. (1985) Holzforsch. Holzverwert. 37, 109; Chem. Abstr. 104, 145539.

44 Lorbeer, E., Zelman, N. (1988) Holzforschung 42, 241-246; Chem. Abstr. 109, 31093

45 Proença, A., Roque, O. R., Cardoso, J. (1977) Bol. Fac. Farmacia Coimbra 2, 9-23

46 Gough, L. J. (1968) Tetrahedron Lett. 3, 295-298

47 Chamy, M. C., Piovano, M., Gambarro, V., Garbarino, J. A., Nicoletti, M. (1987) Phytochemistry 26, 1763-1765.

48 Hongjie, Z., Handong, S. (1989) Phytochemistry 28, 3405-3409.

49 Campello, J. P., Fonseca, S. F. (1975) Phytochemistry 14, $243-248$.

${ }^{50}$ Cambie, R. C., Cox, R. E., Croft, K. D., Sidwell, D. (1983) Phytochemistry 22, 1163-1166.

51 Castro, V., Mojica, E., Calzada, J. (1986) Ing. Cienc. Quim. 10, 5-6.

52 Briggs, L. H., Cambie, R. C., Seelye, R. N., Warth, A. D. (1959) Tetrahedron $7,270-276$

${ }^{53}$ Cambie, R. C., Mander, L. N. (1962) Tetrahedron 18, 465-475

${ }^{54}$ Cambie, R. C., Mathai, K. P. (1971) Chem. Commun. 154-155.

55 Yatagai, M., Shirato, T., Hayashi, Y., Fukuhara, N., Takahashsi, T. (1978) Mokuzai Gakkaishi 24, 267-269; Chem. Abstr. 91, 16655.

56 Fukui, H., Koshimizu, K., Egawa, H. (1978) Agric. Biol. Chem. 42 , $1419-1423$

57 Kobayashi, K., Nishino, C. (1986) Agric. Biol. Chem. 50 2405-2407.

58 Ahn, J. W., Wada, K., Marumo, S., Tanaka, H., Osaka, Y. (1984) Agric. Biol. Chem. 48, 2167-2169.

59 Yatagai, M., Takahashi, T. (1980) Phytochemistry 19, 1149-1151.

${ }^{60}$ Linde, H. (1964) Helv. Chim. Acta 47, 1234-1239.

${ }^{61}$ Narayanan, C. R., Linde, H. (1965) Tetrahedron 41, 3647-3649.

${ }^{62}$ Al-Hazimi, H. M. G., Miana, G. A., Deep, M. S. H. (1987) Phytochemistry 26, 1091-1093

63 González, A. G., Rodriguez, C. M., Luis, J. G. (1987) Phytochemistry $26,1471-1474$.

${ }^{64}$ Dentali, S. J., Hoffmann, J. J. (1990) Phytochemistry 29, 993-994.

65 Bruno, M., Savona, G., Piozzi, F., Torre de la, M. C., Rodriguez, B., Marlier, M. (1991) Phytochemistry 30, 2339-2343.

${ }^{66}$ Paris, R. R., Moise, H. (1976) Matière medicale, p. 386, Masson, Paris.

${ }^{67}$ Font-Quer, P. (1980) Plantas Medicinales, pp. 82-87, Labor, S. A., Madrid.

${ }^{68}$ Kobayashi, K., Nishino, C., Fukushima, M., Shibara, Y., Kodama, M. (1988) Agric. Biol. Chem. 52, 77-83.

${ }^{69}$ Soderberg, T. A., Gref, R., Holm, S., Elmrost, T., Hallmans, G. (1990) Scand. J. Plast. Reconstr. Surg. Hand. Surg. 24, 199-205.
${ }^{70}$ Sodergerg, T. A., Holm, S., Gref, R., Hallmans, G. (1991) Scand. J. Plast. Reconstr. Surg Hand. Surg. 25, 19-24.

71 Sodergerg, T. A. (1990) Scand. J. Plast. Reconstr. Surg. Suppl. 22, $1-87$.

72 Akatsuka, T., Kodama, O., Matsuo, K., Esaki, Y. (1988) Jpn. Pat. 6317805; Chem. Abstr. 109, 106543.

${ }^{73}$ Harima Kasei Kogyo Co. (1980) Ltd. Jpn. Pat. 8072112; Chem. Abstr. 94, 20384.

74 Wada, H., Kodato, S. I., Kawamori, M., Morikawa, T., Nakai, H., Takeda, M., Onoda, Y., Tamaki, H. (1985) Chem. Pharm. Bull. 33, $1472-1487$

75 Onoda, Y., Magaribuchi, T., Tamaki, H. (1989) Jpn. J. Pharmacol. $51,65-73$

76 Ito, Y., Fukushima, T., Sugawara, Y., Takaiti, O., Nakamura, S. (1991) J. Pharmacobio-Dyn. 14, 533-546.

77 Ito, Y., Sugawara, Y., Takaiti, O., Nakamura, S. (1991) J. Pharmacobio-Dyn. 14, 547-554.

78 Onoda, Y., Iwasaki, H., Magaribuchi, T., Tamaki, H. (1991) Arzneim.-Forsch. 41, 546-548.

${ }^{79}$ Kohli, Y., Kato, T., Suzuki, K., Yamazaki, Y., Iwaki, M., Hata, M. (1990) Kyotofuritsu Ika Daigaku Zasshi 99, 1085-1090; Chem. Abstr. 114, 156931.

80 Magaribuchi, T., Onoda, Y., Narida, H., Yabana, H., Yamada, K., Nagasaki, M., Sasaki, Y., Inaeki, M., Yamaguchi, I. (1990) Yakurito Chiryo 18, 4511-4529; Chem. Abstr. 114, 94662.

81 Onoda, Y., Magaribuchi, T., Tamaki, H. (1990) Arzneim.-Forsch. $40,576-578$.

82 Onoda, Y., Takido, M., Magaribuchi, T. (1990) Jpn. J. Pharmacol. $52,63-73$.

83 Sekido, H., Takezawa, J. I., Motori, G., Akatsuka, T. (1990) Agric. Biol. Chem. 54, 287-290.

${ }^{84}$ Vrbosky, L., Siklova, M. (1969) Bratislav. Lek. Listy 53, 275-285; Chem. Abstr. 77, 160082.

85 Fujita, Y., Sempuku, K., Kitaguchi, K., Mori, T., Murai, H., Yoshikuni, Y., Enomoto, H., Löser, R. (1980) Chem. Pharm. Bull. $28,453-458$.

86 Fujita, Y., Yoshikuni, Y., Sotomatsu, T., Mori, T., Ozaki, T., Sempuku, K., Ogino, A., Kise, M., Enomoto, H. (1991) Chem. Pharm. Bull. 39, 1193-1198.

87 Liu, T. P., Gao, C. Z., Feng, L. Z. (1985) J. Tradit. Chin. Med. 5, $115-118$.

${ }^{88}$ Suzuki, A., Asano, M., Ohkubo, C., Tamura, S. (1972) Agric. Biol. Chem. 36, 2051-2053

89 Asano, M., Olikubo, C., Suzuki, A., Tamura, S. (1973) Koshu, Eiseiin Kenkyo Hokoku 22, 1-8; Chem. Abstr. 81, 145821.

90 Karlberg, A. T. (1988) Acta Derm. Veneorol. Suppl. Stockh. 139, $1-43$.

91 Karlberg, A. T., Bergsted, E., Boman, A., Bohlinder, K., Lars, J., Nilsson, G., Wahlberg, J. E. (1985) Contact Dermatitis 13, $209-215$.

92 Karlberg, A. T. (1989) Contact Dermatitis 21, 282-285.

93 Institute for Production and Development Science (1984) Jpn. Pat. 5967219; Chem. Abstr. 101, 78846.

94 Karlberg, A. T., Bohlinder, K., Boman, A., Hacksell, U., Hermannson, J., Jacobsson, S., Lars, J., Nilsson, G. (1988) J. Pharm. Pharmacol. 40, 42-47.

95 Hausen, B. M., Krohn, K., Budianto, E. (1990) Contact Dermatitis $23,352-358$

96 Soderberg, T. A., Elmros, T., Gref, R., Hallmans, G. (1990) Contact Dermatitis 23, 346-352.

97 Ayala, F., Lembo, G., Balato, N., Patruno, C., Scognamiglio, G., Strazzullo, S. S. (1990) Contact Dermatitis 22, 262- 266.

${ }^{98}$ Schuh, B. A., Benjamin, D. M. (1984) J. Econ. Entomol. 77, $802-805$.

99 Fujii, R., Okumura, M., Kine, M. (1986) Jpn. Pat. 61212547; Chem. Abstr. 106, 156857.

100 Proserpio, G., Gatti, S. (1979) Riv. Ital. EPPOSS 61, 53-62.

101 Jonnsen, V. L., Stern, E. S. (1978) U. S. Pat. 4128543; Chem. Abstr. 90,76409 .

102 Emori, S. (1979) Jpn. Pat. 79117037; Chem. Abstr. 92, 64539.

103 Uehara, K., Kawabata, A., Iwasa, S., Inone, Y., Tutsumi, Y., Ichikawa, H. (1988) Jpn. Pat. 63183512; Chem. Abstr. 111; 45052.

104 Uehara, K., Kawabata, A., Iwasa, S., Inone, Y., Tutsumi, Y., Ichikawa, H. (1988) Jpn. Pat. 63183511; Chem. Abstr. 111, 140201. 
105 Takatsu, A. (1991) Jpn. Pat. 3173811; Chem. Abstr. 116, 27852.

106 Ohastti, Y., Yakeuchi, K., Suda, M., Yoshino, K., Kawamata, A., Mastui, Y., Suzuki, Y. (1991) Eur. Pat. 7446938; Chem. Abstr. 116; 22505.

107 Kikuchi, Y., Suzuki, Y., Suzuki, T., Suda, M., Ohashi, Y., Kawamata, A. (1991) Jpn. Pat. 91118311; Chem. Abstr. 115, 263054

108 Le Grouyellec, A. (1985) Fr. Pat. 2557799; Chem. Abstr. 104, 10630.

${ }_{109}$ Collard, A. (1977) Fr. Pat. 2338700; Chem. Abstr. 88, 110544

110 Emori, S. (1979) Jpn. Pat. 79117031; Chem. Abstr. 92, 99466.

111 Ayars, G. H., Altman, L. C., Frazier, C. E., Chi, E. Y. (1989) J. Allergy Clin. Immunol. 83, 610-618.
112 Bushnell, P. G., Nikinmaa, M., Oikari, A. (1985) Comp. Biochem. Physiol C. 81, 391- 394.

113 Mattsoff, L., Nikinmaa, M. (1987) Ecotoxicol. Environ. Safety 14, $157-163$.

114 Oikari, A. O., Nittyla, J. (1985) Ecotoxicol. Environ. Safety 10, 159-172.

115 Patel, G. B., Angew, B. J., Dicaire, C. J. (1991) Appl. Environ. Microbiol. 57, 2969-2974.

115 Orpiszewsk, J., Hebda, C., Szykula, J., Powls, R., Clasper, S., Rees, H. H. (1991) FEMS Microbiol. Lett. 66, 233-236. 